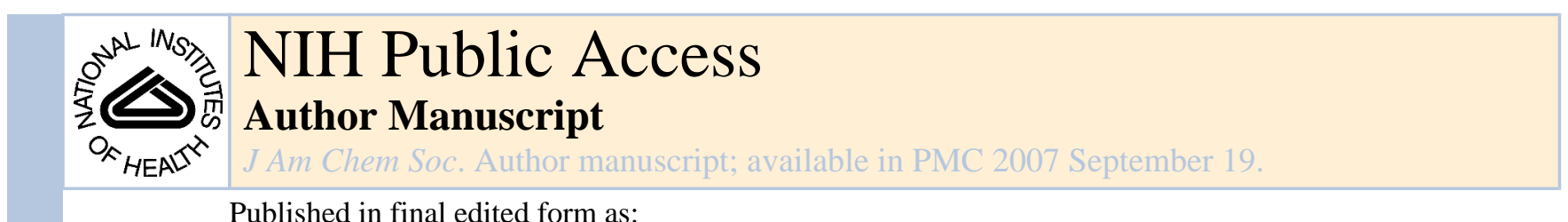

Published in final edited form as:

J Am Chem Soc. 2007 July 18; 129(28): 8702-8703.

\title{
Selective Detection and Quantification of Oxidized Abasic Lesions in DNA
}

\author{
Shanta Dhar, Tetsuya Kodama, and Marc M. Greenberg \\ Department of Chemistry, Johns Hopkins University, 3400 North Charles Street, Baltimore, \\ Maryland 21218
}

Oxidized abasic lesions are produced via a variety of DNA damaging agents and exert distinctive effects on DNA repair and replication. 1,2 With the exception of 2-

deoxyribonolactone ( $\mathbf{L})$ and $\mathbf{A P}$, abasic site (and DNA lesions in general) detection is typically carried out using mass spectrometry, following digestion of the biopolymer, which in some instances is derivatized prior to digestion. ${ }^{3-6}$ Selective tagging of DNA lesions offers the possibility of rapid and sensitive lesion detection without the need for completely degrading the biopolymer or expensive instrumentation. We report a reagent, which when used in conjunction with DNA polymerase $\beta$ and an ELISA like fluorescence assay enables selective quantification of the C4-AP and DOB oxidized abasic lesions. ${ }^{7}$<smiles>COC[C@H]1OC(=O)C[C@@H]1OCOC[C@H]1O[C@H](O)C[C@@H]1OC</smiles>

C4-AP and DOB result from the initial oxidation of the C4'-and C5'-positions of DNA, respectively. Very little is known about the biological effects of DOB, although it is a potential source of the DNA alkylating agent, butene dial. ${ }^{8,9}$ In contrast, C4-AP is known to disrupt replication in $E$. coli and is a substrate for base excision repair. ${ }^{10,11} \mathbf{C 4 - A P}$ is a major component of DNA damage produced by the antitumor agent bleomycin and is also generated by the enediyne natural products, whereas DOB is formed in reactions with neocarzinostatin and enediynes. ${ }^{12-14}$ Both lesions are detected following $\gamma$-irradiation, presumably because of the accessibility of the respective hydrogen atoms to the freely diffusible hydroxyl radical. ${ }^{8}$,

15 C4-AP can be detected in small DNA fragments via gel electrophoresis following reaction with hydrazine. ${ }^{16}$ However, in order to quantify C4-AP or DOB produced randomly in DNA, one typically stabilizes and/or derivatizes the lesions prior to GC/MS analysis. 8,12

E-mail: mgreenberg@jhu.edu

Supporting Information Available: Experimental procedures for the synthesis and characterization of $\mathbf{5}$ and all other experimental procedures; MALDI-TOF MS of DNA adducts and sample fluorescence data. This material is available free of charge via the Internet at http://pubs.acs.org. 


\section{5'-d(CAA GAT TTC AAA TTX GAC GAG CTC AAG CAT) 3'-d(GTT CTA AAG TTT AAA CTG CTC GAG TTC GTA)$$
1 \mathrm{X}=\mathrm{C} 4-\mathrm{AP}
$$$$
\text { 5'-d(TAA TGG CTA ACG CAGOH } \mathbf{X C C} \text { GTA ATG CAG TCT) }
$$$$
\text { 3'-d(ATT ACC GAT TGC GTC—AGG CAT TAC GTC AGA) }
$$$$
2 \mathrm{X}=\mathrm{DOB}
$$

The method described here takes advantage of a common structural feature. The masked 1,4dicarbonyl group in C4-AP and DOB is unique to other lesions and offers the opportunity to develop a reagent that would be useful for their selective detection. We previously reported that DOB reacted with Tris to form a tricyclic adduct in a reaction that is characteristic of 1,4dicarbonyl molecules. ${ }^{17,18}$ Reaction of two Tris analogues $(\mathbf{3}, \mathbf{4})$ with $\mathbf{C 4 - A P}(\mathbf{1})$ indicated that higher adduct yields resulted when a third hydroxyl group was present (Figure 1).

Consequently, $\mathbf{5}$, which could be used in conjunction with a recently developed fluorescence detection method for quantifying lesions was synthesized. ${ }^{7}$ We anticipated that the two lesions could be distinguished by taking advantage of the fact that DNA polymerase $\beta(\operatorname{Pol} \beta)$ excises DOB but not C4-AP (Scheme 1, Figure 2). ${ }^{19}$

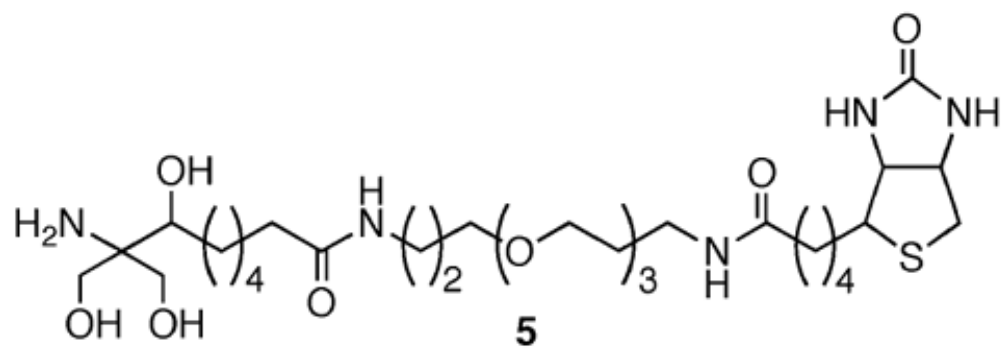

The reactivity of 5 with duplex DNA containing C4-AP (1) or a ternary complex containing DOB $\left(\mathrm{G}^{\mathrm{OH}}\right.$ indicates the 3 '-hydroxyl terminus of the oligonucleotide that flanks DOB, 2) was examined using previously synthesized oligonucleotides containing the lesions at defined sites. 17,20 Optimum conditions for tagging C4-AP $(82.3 \pm 0.1 \%)$ and DOB $(74.8 \pm 0.7 \%)$ were found to be $5 \mathrm{mM} 5$ at $\mathrm{pH} 8.2$ and $55^{\circ} \mathrm{C}$ for $4 \mathrm{~h}$ (Figure 2). Slightly higher adduct yields did not justify using twice the amount $(10 \mathrm{mM})$ of $\mathbf{5}$. No reaction was detected between DNA containing $\mathbf{A P}$ or $\mathbf{L}$ lesions and $\mathbf{5}$ (data not shown). The stereoisomeric mixture of tricyclic adducts were characterized by MALDI-TOF MS. ${ }^{21}$ Treatment of $\mathbf{1}$ with Pol $\beta$ prior to reaction with 5 had no effect on adduct yield (Figure 2). However, no adduct was detected in DOB (2) samples pretreated with $\mathrm{Pol} \beta$, indicating that combined use of the enzyme and $\mathbf{5}$ will enable one to individually quantify these two lesions.

Quantification was carried out by taking advantage of the biotin covalently linked to the DNA through the lesion of interest (Scheme 1). ${ }^{7}$ Lesions were detected by measuring the fluorescence of Resorufin produced from the oxidation of Amplex Red by horseradish peroxidase. Absolute amounts were determined using a calibration curve established side-byside and by taking into account the adduct yields, per above. ${ }^{21}$ Experiments with $\mathbf{1}$ and $\mathbf{2}$ indicated that the signal varied linearly over an order of magnitude and one could readily detect 25 fmol of adduct. ${ }^{21}$ The method was initially tested by analyzing the reaction of peplomycin with a PCR fragment produced by amplifying a $287 \mathrm{nt}$ region of M13 plasmid (Figure 3). This experiment verified that $\mathbf{C 4 - A P}$ formation depended linearly on the concentration of the bleomycin analogue.

J Am Chem Soc. Author manuscript; available in PMC 2007 September 19. 
Having established the fluorescent assay, $\mathbf{5}$ was used to measure the levels of $\mathbf{C 4 - A P}$ and DOB produced in the PCR fragment exposed to $\gamma$-radiolysis (Figure 4). The amounts of adduct (s) with and without $\mathrm{Pol} \beta$ treatment were indistinguishable under aerobic conditions, indicating that the amount of DOB produced under these conditions was significantly less than that of C4-AP. The total amount of lesions formed decreased $\sim 3$-fold under anaerobic conditions, consistent with the $\mathrm{O}_{2}$ enhancement effect in $\gamma$-radiolysis. ${ }^{15}$ However, under anaerobic conditions DOB accounted for $\sim 16 \%$ of the lesions detected. Comparing these data to those recently reported reveals that the total amount of 1,4-dicarbonyl containing lesions formed by $\gamma$-radiolysis under aerobic conditions account for $\sim 27.5 \%$ of the total amount aldehyde reactive DNA damage. ${ }^{5}$ Furthermore, these experiments are consistent with the proposal that 2deoxyribonolactone $(\mathbf{L})$ is the major abasic lesion produced by ${ }^{137} \mathrm{Cs}$ irradiation of DNA in aqueous solution, despite the $\mathrm{C} 1$ '-hydrogen atom's inaccessibility to diffusible species. 5 , 22-24 Overall, this study indicates that $\mathbf{5}$ is a useful research tool for selectively detecting two significant DNA lesions at femtomolar levels. The method will enable one to utilize the C4$\mathbf{A P}$ and DOB abasic lesions as biomarkers.

\section{Supplementary Material}

Refer to Web version on PubMed Central for supplementary material.

Acknowledgment

We are grateful for generous support from the National Institute of General Medical Sciences (Grant GM-063028) and for a Japan Society for the Promotion of Science Postdoctoral Fellowship for Research Abroad to T.K. We thank Dr. Liang Xue for technical assistance and helpful suggestions, Professor Hiroshi Sugiyama for peplomycin, and Dr. David M. Wilson for DNA polymerase $\beta$ as well as helpful comments on the manuscript.

\section{References}

1. Hashimoto M, Greenberg MM, Kow YW, Hwang J-T, Cunningham RP. J. Am. Chem. Soc 2001;123:3161-3162. [PubMed: 11457038]

2. Kroeger KM, Jiang YL, Kow YW, Goodman MF, Greenberg MM. Biochemistry 2004;43:6723-6733. [PubMed: 15157106]

3. Lhomme J, Constant JF, Demeunynck M. Biopolymers 1999;52:65-83. [PubMed: 10898853]

4. Sato K, Greenberg MM. J. Am. Chem. Soc 2005;127:2806-2807. [PubMed: 15740088]

5. Xue L, Greenberg MM. Angew. Chem., Int. Ed 2007;46:561-564.

6. Dizdaroglu M, Jaruga P, Birincioglu M, Rodriguez H. Free Radical Biol. Med 2002;32:1102-1115. [PubMed: 12031895]

7. Xue L, Greenberg MM. J. Am. Chem. Soc 2007;129:7010-7011. [PubMed: 17497789]

8. Chen B, Bohnert T, Zhou X, Dedon PC. Chem. Res. Toxicol 2004;17:1406-1413. [PubMed: 15540938]

9. Byrns MC, Vu CC, Neidigh JW, Abad J-L, Jones RA, Peterson LA. Chem. Res. Toxicol 2006;19:414420. [PubMed: 16544946]

10. Kroeger KM, Kim J, Goodman MF, Greenberg MM. Biochemistry 2004;43:13621-13627. [PubMed: 15504024]

11. Greenberg MM, Weledji YN, Kroeger KM, Kim J, Goodman MF. Biochemistry 2004;43:2656-2663. [PubMed: 14992603]

12. Rabow LE, Stubbe J, Kozarich JW. J. Am. Chem. Soc 1990;112:3196-3203.

13. Xi, Z.; Goldberg, IH. In Comprehensive Natural Products Chemistry. Kool, ET., editor. 7. Elsevier; Amsterdam: 1999. p. 553-592.

14. Goldberg IH. Acc. Chem. Res 1991;24:191-198.

15. von Sonntag, C. The Chemical Basis of Radiation Biology. Taylor \& Francis; London: 1987.

16. Sugiyama H, Kawabata H, Fujiwara T, Dannoue Y, Saito I. J. Am. Chem. Soc 1990;112:5252-5257.

17. Kodama T, Greenberg MM. J. Org. Chem 2005;70:9916-9924. [PubMed: 16292822]

J Am Chem Soc. Author manuscript; available in PMC 2007 September 19. 
18. Maiereanu C, Darabantu M, Plé G, Berghian C, Condamine E, Ramondenc Y, Silaghi-Dumitrescu I, Mager S. Tetrahedron 2002;58:2681-2693.

19. Nguyen LH, Barsky D, Erzberger JP, Wilson DM. J. Mol. Biol 2000;298:447-459. [PubMed: 10772862]

20. Kim J, Gil JM, Greenberg MM. Angew. Chem., Int. Ed 2003;42:5882-5885.

21. See Supporting Information.

22. Balasubramanian B, Pogozelski WK, Tullius TD. Proc. Nat. Acad. Sci. U.S.A 1998;95:9738-9743.

23. Roginskaya M, Razskazovskiy Y, Bernhard WA. Angew. Chem., Int. Ed 2005;44:6210-6213.

24. Hong IS, Carter KN, Sato K, Greenberg MM. J. Am. Chem Soc 2007;129:4089-4098. [PubMed: 17335214] 


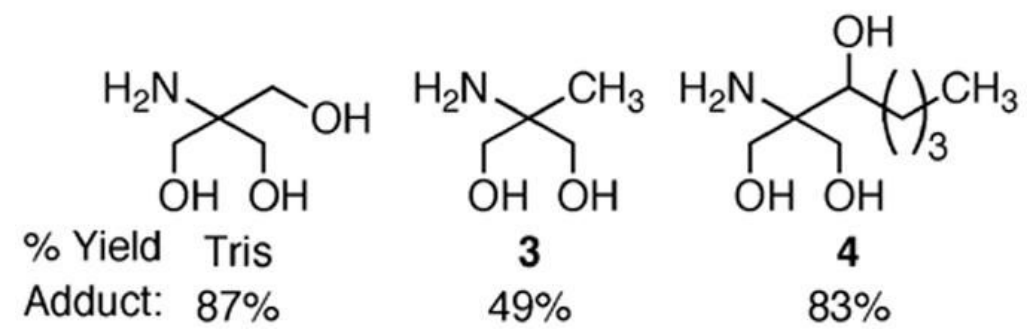

Figure 1.

Yields of adduct with C4-AP (1). 


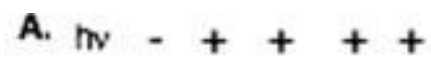

B. $\mathrm{hv}-+++++$

$\mathrm{NaOH}-++-\cdot-\cdot$

$\mathrm{NaBH}_{4}-\cdot++\cdot-\cdot$

$5---++-+$

$\mathrm{Pol} \beta-+-++$

Adduct

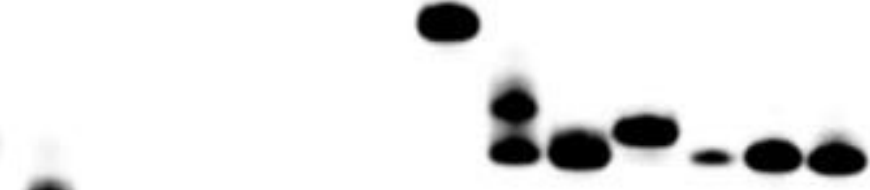

Figure 2.

Reaction of $5\left(5 \mathrm{mM}, \mathrm{pH} 8.2,55^{\circ} \mathrm{C}, 4 \mathrm{~h}\right)$ with DNA containing (A) C4-AP (1) or (B) DOB (2). 


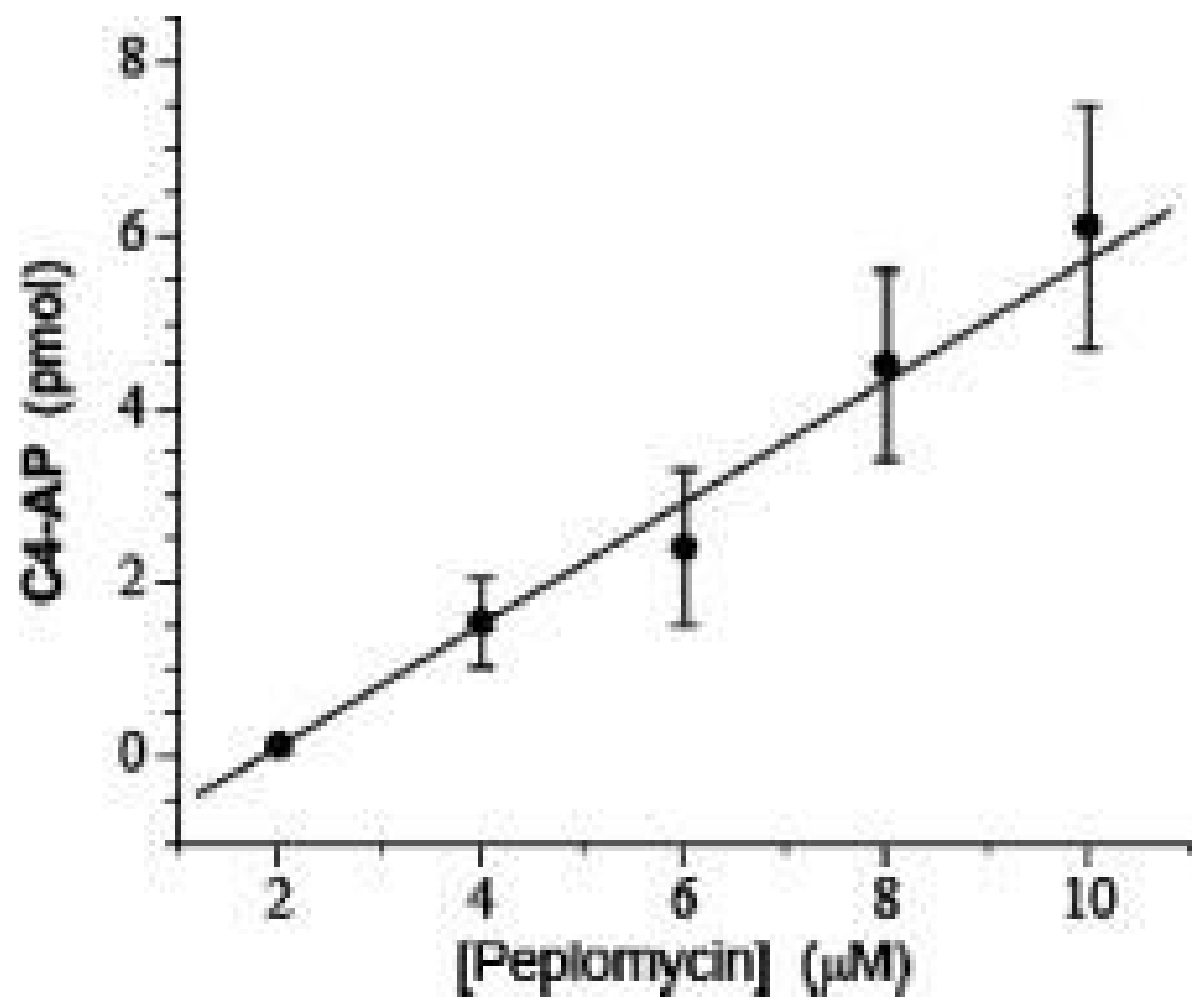

Figure 3.

C4-AP formation as a function of peplomycin concentration. 


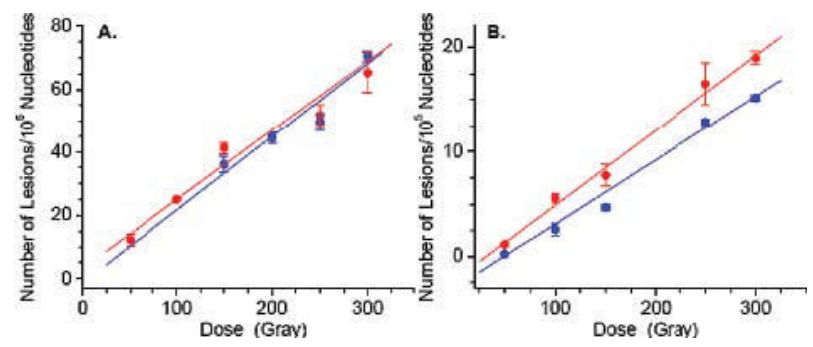

Figure 4.

Quantification of C4-AP and DOB production by $\gamma$-radiolysis of the $287 \mathrm{nt}$ PCR fragment under (A) aerobic (B) anaerobic conditions: with $\operatorname{Pol} \beta$, blue; without $\operatorname{Pol} \beta$, red. 


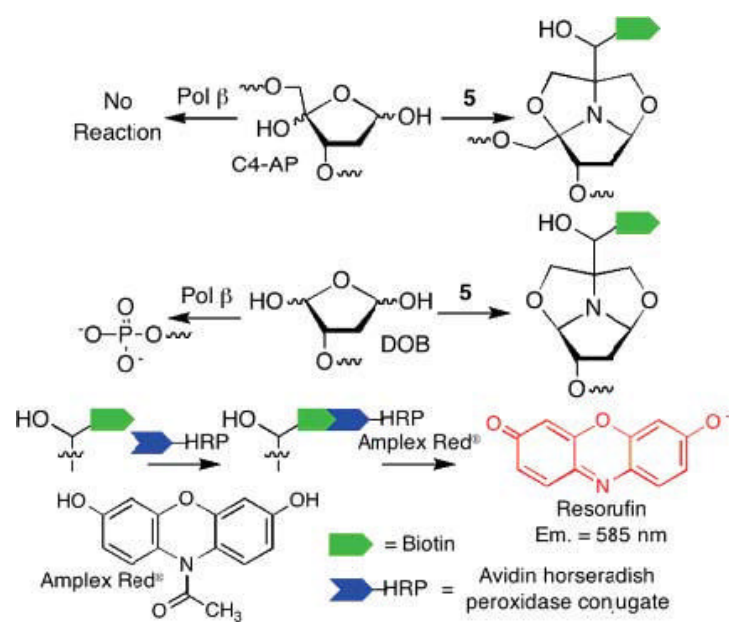

Scheme 1.

Fluorescence Detection of C4-AP and DOB Using 5 